\title{
TRENDS IN RESEARCHERS' EDUCATION FOR ENVIRONMENTAL EDUCATION AND EDUCATION FOR SUSTAINABLE DEVELOPMENT
}

\author{
Luiz Marcelo de Carvalho ${ }^{1}$ \\ Marina Battistetti Festozo ${ }^{2}$ \\ Daniel Fonseca de Andrade ${ }^{3}$ \\ Flávia Torreão Thiemann ${ }^{4}$
}

\begin{abstract}
In this paper we discuss how recent developments tied to the current neoliberization climate, such as an increased reliance on publication metrics, percolate through the process of researchers training and education, casting a shadow over hiring, funding and choice of publication venue criteria, drawing on examples from Brazil and other countries. At the same time, we present a number of movements that have sprouted in response to this perceived undue influence and may open up new avenues for the academic community that allow for more diversity while preserving the university's role in preparing and supporting new generations of researchers. We tried also to put in evidence the consequences and the possibilities that these resistance movements can bring to the field of environmental education.
\end{abstract}

Key words: Performativity. Process and evaluation of knowledge production. Evaluation of postgraduation. New researcher's education.

\section{TENDENCIAS EN LA EDUCACIÓN DE PESQUISIDORES PARA LA EDUCACIÓN AMBIENTAL Y LA EDUCACIÓN PARA EL DESARROLLO SOSTENIBLE}

\section{Resumen}

En este texto proponemos evidenciar y poner en circulación las posibles relaciones entre las actuales tendencias neoliberales que han influenciado el proceso de producción del conocimiento científico $\mathrm{y}$, consecuentemente, los procesos de formación de futuros investigadores. Tomando como ejemplo situaciones concretas que hemos vivido en Brasil y algunos otros países, buscamos, además, explicitar las relaciones entre tales tendencias y los procesos de evaluación de los investigadores individualmente y de los programas de postgrado, locus privilegiado de formación de nuevos investigadores. Al mismo tiempo, ponemos en relieve algunos movimientos de resistencia que han sido creados para responder a esas tendencias, y que apuntan a nuevas perspectivas que permitan una mayor diversidad de experiencias y de procesos formativos, con el objetivo de garantizar y preservar el papel de las universidades en preparar y formar una nueva generación de investigadores. Aún, destacamos las consecuencias de tales tendencias y las posibilidades que se abren con los movimientos de resistencia para el propio campo de pesquisa de la Educación Ambiental.

Palabras clave: Performatividad. Proceso de producción del conocimiento científico. Evaluación de la producción científica. Evaluación del postgrado. Formación de nuevos investigadores.

\footnotetext{
${ }^{1}$ Unesp - Instituto de Biociências, Depto. de Educação. lmarcelo@rc.unesp.br

${ }^{2}$ Departamento de Biologia - Setor de Educação Científica e Ambiental, Universidade Federal de Lavras.

Lavras, MG, Brasil. marina.festozo@dbi.ufla.br

${ }^{3}$ Instituto de Biociências, Universidade Federal do Estado do Rio de Janeiro. Rio de Janeiro, Brasil

${ }^{4}$ Senior Researcher, Fubá Educação Ambiental e Criatividade LTDA. São Carlos, Brazil.

flaviathiemann@yahoo.com
} 


\title{
TENDÊNCIAS DA EDUCAÇÃO DE PESQUISADORES EM EDUCAÇÃO AMBIENTAL E EDUCAÇÃO PARA O DESENVOLVIMENTO SUSTENTÁVEL
}

\begin{abstract}
Resumo
O nosso objetivo, neste texto, é o de procurar evidenciar e colocar em circulação as possíveis relações entre as atuais tendências neoliberais que tem influenciado o processo de produção do conhecimento científico e, consequentemente, os processos de formação de futuros pesquisadores. Tomando como exemplo situações concretas que temos vivenciado no Brasil e alguns outros países, procuramos, ainda, explicitar as relações entre tais tendências e os processos de avaliação, tanto dos pesquisadores individualmente quanto dos programas de pós-graduação, lócus privilegiado de formação de novos pesquisadores. Ao mesmo tempo, procuramos evidenciar alguns movimentos de resistência que têm sido criados para responder a essas tendências, e que apontam para novas perspectivas que permitam uma maior diversidade de experiências e de processos formativos, visando garantir e preservar o papel das universidades em preparar e formar uma nova geração de pesquisadores. Ainda, buscamos evidenciar as consequências de tais tendências e as possibilidades que se abrem com os movimentos de resistência para o próprio campo de pesquisa da Educação Ambiental.
\end{abstract}

Palavras-chave: Performatividade. Processo e avaliação da produção do conhecimento científico. Avaliação da produção científica. Avaliação da pós-graduação. Formação de novos pesquisadores.

\section{Introduction}

Debates continue about the purposes, roles and objectives of universities in contemporary societies around the world. These higher education institutions are often viewed by various social sectors, as well as by the academia itself, as being in crisis. Such debates have, in turn, fueled questions, controversies and diverse political and ideological positions concerning the function of these millennial institutions (SANTOS, 2004; SIMONS; MASSCHLEEIN, 2009). Meanwhile, the global, planetary crisis of increasing ecological unsustainability bring into sharp relief a fundamental challenge for universities, that is to promote an ecologically sustainable vision of its educational role and research purposes.

Considering this context, what we find significant to contemplate is that, over time, universities' role in relation to the process of educating and training new professionals and producing new knowledge has been historically recognized. There appears to be relatively consensual position on this debate (GOERGEN, 1998; SOBRAL, 2000; AROCENA; SUTZ, 2001; SEVERINO, 2002; 2009; MASSCHLEIN; SIMONS, 2009; SIMONS; MASSCHLEIN, 2009; LEATHWOOD; READ, 2013). Seen as an intrinsic consequence of these two basic roles, namely, the production of knowledge and the education of professionals, the intergenerational and cross sectoral processes of training new researchers in any area of knowledge have been considered as one of the basic tasks of modern universities (BOGLE, et al, 2011). Thus, it is important to reflect upon and search for ways to train researchers who are committed to processes of constructing a socially and environmentally fairer world in such different areas of the scientific field. This challenge involves ongoing discussion on the role of universities in the contemporary world, reflection on current trends in knowledge production processes and also in the policies for the evaluation of this primary function of universities.

In this regard, recognizing that graduate programs offered by universities - Master's 
and Doctoral Programs - are the privileged loci for training new researchers, we believe that it is also of great relevance to reflect on the role, meaning, and sustainability of such programs. It is in graduate programs that new researchers begin their training as knowledge producers, become independent and start participating in the processes of training of other researchers.

Thus, public policies for the implementation, financing and evaluation of this level of the educational system play an essential role, considering that they not only interfere with, but in many ways, determine the conditions for the training of future researchers (CARVALHO; TOMAZELLO; OLIVEIRA, 2009; CARVALHO, 2016). These are some of the reasons why we consider both, that is, the trends in the processes of new knowledge production by universities, and trends in postgraduate systems evaluation, as priorities when we aim to discuss the processes of training new researchers.

Thus, in this text, we seek to explore - among other equally important and relevant aspects - two features that have guided current trends in knowledge production processes. On the one hand, the culture of performativity and, on the other, the current national and international policies regarding universities. These policies have had a sharp influence on the financing and evaluation of the production of new knowledge by universities and the processes of training new researchers through graduate systems.

Among them, we consider quite significant to reflect on the strong tendency that is referred to by some authors (see, for example, MOREIRA, 2009, p. 23) as the "culture of performativity", which has been fostered as a criterion for evaluating and financing graduate programs. The second aspect, of a more theoretical nature, is the need to recognize investigative activity as a social practice, one of the main objectives of which is the production of theories about reality.

As to the "culture of performativity", the French philosopher Jean-François Lyotard defines "performativity" as an "accounting-style" assessment of personal performance (JAMES; McQUEEN-THOMSON, 2002, p. 187). Smeyers and Burbules (2011, p. 9) suggest that it embodies a "quantification of qualitative criteria". This culture is criticized because it overemphasizes the quantitative features and outcomes of research, seeing this, in part, as an unfortunate aversion to theoretical production, a devaluation of the intellectual attitude and a tendency to consider published "papers" as "products", as ends in themselves, (BIANCHETTI; MACHADO, 2007, p. 3). Others claim that this culture may limit the possible values, meanings and utilities of research, and minimize the theoretical consistency of investigations, which are aspects considered to be of great significance for the process of knowledge construction (SEVERINO, 2006; SGUISSARD, 2006).

Payne (2009) is clear when he calls our attention for the threat that this kind of police can represent for universities:

In the North/West, there is growing concern that the role and identity of universities is undergoing rapid change as neo-liberal imperatives convert universities to a 'crisis' like condition where globalized approaches to knowledge production are viewed critically as a severe political threat (COADY, 2000; COOPER, HINKSON \& SHARP, 2002) (PAYNE, 2009, p, 64)

An emphasis on performativity has a cost in time for researchers to reflect and theorize on the research processes themselves, as well as how such research advances the field conceptually and empirically. This is the second aspect we wish to explore in this paper. In particular, searching questions need to be asked about the quality, or not, of the products and outcomes of the performative culture, directly associated with the current evaluation policies for graduate programs. Some consider that the non-reflective push to performativity has only served to exacerbate competitiveness amongst researchers and their institutions, and to foster bureaucratically centralized conditions for hyper control, over regulation and poor evaluation of research programs (MOREIRA, 2009). Not only may such trends have negative impacts on 
knowledge production processes, but also in processes of researchers' training (CARVALHO; TOMAZELLO; OLIVEIRA, 2009). Thus, despite our expectations that universities are places of reflection and critical thinking, we observe the weakening of such spaces as places for investigation and the construction of theoretical and methodological frameworks that serve as a basis for producing original and meaningful knowledge (PAYNE, 2009). Universities, when subjected to evaluations that emphasize productivity, lose space as institutions that are "capable of deploying knowledge for critical and interpretative purposes" (COOPER, 2002, p. 217).

Within this broad framing, two particular questions emerged from the discussions in the Environmental Education Researcher Training Policies sub-theme of the $13^{\text {th }}$ International Seminar on Environmental Education Research, carried out in Brazil, July, 2015. The overall theme for the seminar was: "What is critical about contemporary "critical" environmental education research: theoretical challenges, tensions, applications, methodological implications?". We then asked:

1 - To what extent have international policies for knowledge production and the monitoring and evaluation of graduate programs, on the one hand, promoted tendencies that foster performativity or, on the other, that favor the training of critical researchers in EE?

2 - What kind of research and training practices or academic habitus could we develop in order to implement training processes aimed at fostering critical researchers?

\section{Trends in knowledge production and researchers' training}

One of the many implications of the culture of performativity in universities is that the quasi-exclusive focus on the quantitative dimension of production. This, as observed from a number of publications, begins to show its limits, since, with the increase in the number of journals and publications, "everybody is writing for nobody" (WALS; DILLON, 2013, p. 258). The study by Freitas (2011), which refers to both Brazilian and international scenarios, corroborates the abovementioned authors' assertion, what can also be noted in Oliveira and Almeida's studies (2011). In Brazil for example, although we can observe an increase in the number of scientific journals and papers, published in a 13-year period (1996-2008) - citations of Brazilian publications have "dropped from 11.81 to 0.74 per publication over that period, which means that in 2008 there were approximately 6.3\% of the citations obtained in 1996. This same trend can be observed in other countries as well: in the United States, for example, there were only $6.98 \%$ of the citations obtained in that same period; in the United Kingdom, $7.58 \%$, and in Germany, 8.33\%" (FREITAS, 2011, p. 28). Freitas (2011) concludes that citations have decreased all over the world, that researchers can no longer read all that is published and cite their peers less often, and also that the quality of the world scientific production is falling precipitously, including that of Brazilian research.

For Wals and Dillon (2013), this focus on the quantitative aspects of production is promoting a disconnection between universities and the communities that support them, which should have some of their needs provided for by the former's work. The focus on efficiency makes merit attribution be based on measurable criteria, such as the number of articles published, more specifically in journals (COOPER; POLETTI, 2011). This disregards other activities performed by researchers, such as extension activities aimed at communities. Another negative aspect pointed out by these authors (COOPER; POLETTI, 2011; WALS; DILLON, 2013) is the fragility of the system's being supported by peer review. The increase in the number of article submissions has overwhelmed the researchers invited to review them. For Cooper and Poletti (2011), the peer-review process is not reliable, since the large number of articles submitted does not allow for their thorough review. For Wals and Dillon (2013), fragility is related to the fact that this system privileges only the publishers, since reviewers 
are not remunerated for the work.

For Osterloh and Frey (2009), at least four fundamental disadvantages exist for researchers in the use of productivity-based rankings. First, researchers' intrinsic curiosity, which moves them to produce scientific work, could be replaced by the external motivation to respond well to rankings and to obtain rewards. By doing so, the importance of the quality of content is supplanted by that of quantity; and the intrinsic or authentic pleasure of doing research is shifted to the value of its form commoditized into a product. Second, there is loss of autonomy, as researchers become assessed almost exclusively by quantitative criteria, which ultimately will guide and stimulate their production, especially when they are associated with financial incentives. In this context, researchers are induced to shift their scientific objectives and create strategies to be successful in the game, which reinforces the instrumental doing of science. This process leads, in the third place, to a kind of a negative self-selection, since researchers who prioritize survival in the game (and not doing science) will be rewarded. Finally and fourthly, the self-prophecy, that productivism based on extrinsic motivation is, in fact, the best way to direct science, is fulfilled.

In a study conducted with 71 researchers in the United Kingdom, Leathwood and Read (2013) raised such researchers' concerns about the performativity culture in relation to the impact of that culture on research and academic work. As a result, they found out that there is a higher probability that certain types of research and researchers, who work based on already established paradigms, are privileged in relation to others, who explore more innovative perspectives, such as those related to qualitative, critical, post-critical, feminist, post-feminist, post-structuralist research and other types.

From a different perspective, Gill (2009), when writing about the consequences of the neoliberal academy - which is how she refers to the context of induced individualization, of the "audit culture" (p.231) and of the self-monitoring that prevails in universities today - on academics, uses words such as "exhaustion, stress, overloading, insomnia, anxiety, shame, aggression, pain, guilt, feelings of displacement, fraudulence and fear of exposure" (p. 229). To her, these affective feelings are common and everyday, but remain silent and secretive in the public spaces of the academy.

The consequences of the culture of performativity especially affect the daily lives of young professors and researchers, causing a sense of insecurity and uncertainty in face of the professional environment. Such professors and researchers feel inadequate, precisely because they do not believe that their ability can fit, in due time, the predominant criteria of "authenticity" (ARCHER, 2008, p. 387) and success related to the production of a minimum number of scientific papers annually or to the pursuit of external resources (ARCHER, 2008). Results of the study carried out by the author showed an atmosphere of uneasiness among new researchers due to the highly selective criteria of productivity and the perceptions of future. In this context, it is an exigence to continually re-perform in a scenario of scarcer resources, so that the professional status that they have achieved is not lost. Young professionals have realized that a successful and authentic academic identity is not only a very difficult thing to achieve, but it is also an "insecure, temporary and risky" condition (ARCHER, 2008, p. 392). Leathwood and Read (2013), resume the aspects pointed out by Archer (2008) and reinforce the great concern regarding young researchers, who need, in addition to appropriating the very issues related to their early careers, to "play the game" (p. 1172) of obtaining financial support and publishing.

Another outstanding issue among the research subjects in the studies by Leathwood and Read (2013) was the question related to the impact of researchers' work on the field of research. Respondents emphasized the difficulty of really measuring the impact of a study, for example, and the impossibility of doing so in advance, especially if it is innovative. In addition, they also stressed that research can be important even if it has no impact, as long as 
it brings input or broadens understanding on a particular topic.

Amongst these different attempts at evaluating scientific production, the idea of measuring the impact of researchers' work, known as the "impact factor", has gained significant space among research evaluation and funding organizations (SMEYERS; BURBULES, 2011). These authors describe how the publishing company Thompson Reuters uses journals indexed in its Web of Science database to calculate the impact factor of a journal. Impact factors are calculated based only on citations of journals indexed in the database used. Smeyers and Burbules (2011) draw attention to the risks regarding the overemphasis on the use of the impact factor and other metrics in judging the value of a researcher or a particular study. Such tendency eventually directs and influences not only research topics and methodologies to be explored in future studies or the choice of journals in which to publish, but also editors' decisions about what to publish. According to these authors, one can also observe, among young researchers, a tendency to start their research on topics that offer greater chances of being published in journals with a higher impact factor. The authors also call attention to the fact that, in several countries, impact factors are part of the evaluation of candidates for job vacancies in universities, for researchers' promotion and for the allocation of research resources. The same tendency is pointed out by James and McQueen-Thomson (2002, p.193), when they say that "academic appointments, promotions and funding allocations are highly dependent upon the codified system of publishing new research in refereed academic journals". Therefore, this metric ends up influencing public policies, since it is an important factor in granting research funds.

The implications of these trends in the quantification and measurement of scientific production and of researchers' work, associated with other tendencies related to mechanisms for hiring researchers and professors, have been recognized by some authors as results of neoliberal policies applied to universities. Lucal (2015), for example, when reflecting on how this context has impacted higher education in the United States, focuses on two aspects: the reduction of full-time and tenure positions and the proportional increase in these professionals' workload. Hence, the increase in the workload and responsibilities for full-time and tenure researchers as well as that in temporary work positions - which are subject to periodical evaluations for work contract extensions - have led to the consequent depoliticization and loss of resistance capacity of institutions. As we know, stability is a condition that fosters or allows these professionals to denounce and refuse agreeing with changes currently taking place in the name of neoliberalism.

The value that has been attributed to the impact factor metric can also influence a university's very organization. Using the specific case of their own university as an example (Guent University, Belgium), Smeyers and Burbules (2011) draw attention to the fact that the number of positions available by department is a function of the number of doctoral students who receive their degrees in a specific field. Another factor considered is the capacity of such field to receive research funding, which is related to the impact factor of the journals in which the department publishes its research.

Goldani, Silva, Nascimento and Blank (2010) analyze the change in the organizational profile of knowledge-producing institutions in developed countries in the last 50 years. Considering reality in a dialectical fashion, we note that some consequences of this model can equally bring isolated and/or apparent improvements. However, it is important to keep in mind, as these authors argue, that there has been a shift to more individual choices, in which researchers, in a more isolated fashion, have worked to find answers to their research questions according to a corporate model, determined by "large research institutes and their financing agencies" (...) that "currently follow the influences of a market-oriented scenario" (GOLDANI, et al 2010, p. 105-106). Such changes, according these authors, are materialized by means of "greater control of research lines and their researchers", reduction of the fixed 
budget and greater need to raise external resources, demanding - and consequently causing improvement of administrative processes in order to pursue these objectives.

What is important to stress from what has been seen above is that current practices of knowledge production and dissemination, and of production evaluation and monitoring, driven by a neoliberal paradigm, have subjected academics to rules that are stipulated by an international system of production quantification and its questionable impact that prioritizes quantity rather than social relevance. Such procedures have greatly exacerbated the pace of work in universities and research institutes, affecting the physical and psychological health of researchers and their state of well-being. These contexts eventually favor the race for production and, more and more, place the processes of professors and researchers' training in a secondary level of importance in graduate programs (YAMAMOTO, TOURINHO, BASTOS, MENANDRO, 2012).

\section{Initiatives/strategies/possibilities of constructing a culture of reflexivity and a "new habitus" in researchers?}

Although the approximation between knowledge production, its financing and market interests is clear to observe, we have also found in the literature evidences of resistance movements as well as movements towards the construction of alternative ways for knowledge production and its evaluation. In this paper, we present different initiatives from different countries, such as Brazil, United States, United Kingdom and Belgium.

Such resistance initiatives for the construction of alternative ways to validate academic work by valuing the results of the research conducted and the training of researchers, point to attitudes of individual researchers, of research groups or of a network of researchers, and sometimes to actions that are consolidated from institutional decisions.

For example, Lucal (2015) suggests that the inevitability of the neoliberal regime should be rejected in the discourse of professors and researchers and that the arguments about the benefits that it can bring to us should be actively questioned. Lucal's (2015) recommendation is that professionals and institutions engage in the offer of pedagogical experiences that stimulate the development of students' critical sense and motivate them to become involved in these resistance movements.

Archer (2008), in her work, describes some attitudes emerging among new professionals that can be regarded as forms of resistance to this conjuncture. She emphasizes the fact that some new researchers adopt some critical and reflexive attitudes in relation to the dominant practices, appropriating traditional discourses, for example with the praise of notions of collegiality. For Archer (2008), this is a demonstration of the power and resilience of the more traditional academic culture, which continues to be embraced and reworked by the new generations.

According to Leathwood and Read (2013), there is much evidence of resistance in the academy against the culture of performativity, even when it comes from individual actions of professors or groups. Examples emphasized by the respondents in their study included insistence on matching work hours to those in the contract, preference for publishing in journals with the largest peer audience, in spite of their impact factor, respecting their own work pace instead of performative demands (mainly by senior professors and those near retirement), requesting transference to exclusive teaching contracts and, finally, abandoning the field.

However, to the authors, even if such evidence has produced results for these specific individuals or groups, it has failed to bring about broader outcomes, and discourses of performativity do not appear to have been significantly affected. The authors still question who can resist these discourses and in what form. To them, the study outcomes have 
demonstrated many contestations and criticisms, but few examples of active resistance behaviors that have reached beyond that. In the same study, they were able to identify that most respondents were, on the other hand, complying, albeit reluctantly, with the imperatives of performativity (that is, investing in improving their publications and pursuing funds), despite personal costs in terms of extra work, stress and reduced sleep. Many of the attempts to meet this demand stem from the pressure imposed on them by their institutions through mentors, evaluations, goals, public monitoring of productivity, direct orders and even threats of dismissal or reduction of their work contracts to contracts involving exclusively teaching activities.

As to the competition context generated by current policies for knowledge production and research evaluation and funding, Fang and Casadevall (2015) indicate that a form of resistance would be a significant change in the economic structure of science, with the recovery of public investments. In practical terms, the authors suggest the incorporation of a strategy, which has already been used in some cases, that is to establish arrangements among different groups so that their investigations be carried out through collaborative research projects and solidary practices of knowledge production and dissemination of their studies.

Moreover, in regard to the concentration of journals in the hands of the private sector, which limit the dissemination of publicly financed studies, some initiatives seem to be promising. There can already be found records of resistance movements that have arisen contrarily to the hegemonic publishing practices, especially in the field of "hard sciences". One of them was the creation of the Public Library of Science - PloS in 2001. Papers published in their journals are freely accessible (https://www.plos.org/) from the time of their publication. Other moves include article-sharing Websites, such as Researchgate (https://www.researchgate.net/ ) and Academia.edu (https://www.academia.edu/). These Websites work as networks of researchers that facilitate the free distribution of scientific papers, even those published in journals with restricted access. The use of alternative browsers, such as the Google Scholar database, which is not restricted to the journals of any particular publisher and, hence, more diverse, may eventually diminish the current relevance of impact factors (SMEYERS; BURBULES, 2011).

Wals and Dillon (2013) also indicate other resistance initiatives, such as the resurgence of a movement that seeks to connect society's demands with the development of research, the science shops. According to the organization Living Knowledge, these are organizations "created as mediators between citizen groups (trade unions, pressure groups, non-profit organizations, social groups, environmentalists, consumers, residents' associations etc.) and research institutions (universities, independent research facilities). Science Shops are

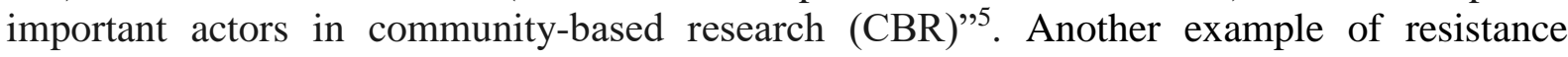
mentioned by the authors is the formation of new networks of "community-engaged universities" (WALS; DILLON, 2013, p. 258) in several countries and of centers of expertise. In these centers, universities associate with the civil society organized in NGOs and community groups to develop participatory research. Likewise, some universities and university networks are beginning to value social relevance as a key criterion of quality and extending peer review to user groups (WALS; DILLON, 2013, p.259).

\section{Resistance Initiatives and the Field of Research in Environmental Education}

From the experiences with which we have come in contact regarding research practices in EE, by different research groups in Brazil and in other countries, it seems

\footnotetext{
${ }^{5}$ Available at www.livingknowledge.org
} 
plausible to agree with the assertion by Carvalho, Tomazello and Oliveira (2009). In their paper, the authors state that "the majority of research in environmental education in Brazil is carried out in higher education institutions by graduate programs" (p. 20). Therefore, although as the authors themselves acknowledge this is not a particular and exclusive condition of EE research, graduate programs are recognized as a privileged path in our knowledge production practices in the fields of education in general and of EE in particular.

Thus, we assume that in exercises of analysis of the field and of our research practices in education and in $\mathrm{EE}$, the close relationship between knowledge production in environmental education and the higher-education and graduate systems in the country deserves special attention.

As such, it does not seem possible to leave aside the construction of resistance movements and the counterpoints to a number of difficulties and limitations resulting from policies for graduate programs in the country, especially with regard to those related to the financing, evaluation and the monitoring of such programs. As we pointed out, we understand that those policies have fostered practices that meet the demands of the culture of performativity and have fueled a climate of great competition among researchers. This concern has already been pointed out by scholars in other fields, as seen above, and also in EE (see, for example, Robottom and Hart, 1993).

It becomes relevant, therefore, to consider the possibilities, particularities and nuances of forms of resistance in different countries in the specific case of EE. When we revisited the discussions and outcomes of the workshop on "Training Policies for Researchers" that was held during the $13^{\text {th }}$ International Seminar on Environmental Education Research ${ }^{6}$, some perspectives related to such resistance policies could be recognized. Among other things, seminar participants were invited to reflect on current EE knowledge production policies and on the extent to which such policies have limited the processes of researchers' education in more comprehensive critical approaches. In addition, participants were encouraged to bring out researcher training initiatives developed in their realities that could somehow respond to the objective of resisting to such policies and foster researchers' training processes in the perspective considered to be central during the seminar discussions.

The analysis of the contributions made by the workshop participants allows us to point out that among the most significant issues to be considered in processes of researchers' education aiming at the emergence of critical thinking and practices is the construction of intellectual autonomy. Intellectual autonomy allows researchers to establish clear theoretical and methodological frameworks that support their knowledge production practices. In addition, participants also emphasized aspects that are related to the environments in which such researchers are educated, and stressed the importance of developing links between young researchers and the search for the creation of identities for research groups.

Thus, a first issue addressed by workshop participants as a form of resistance to the culture of performativity in the processes of researchers' education was the encouragement given to young researchers to read thoroughly about the field of EE. The justification for such behavior is that $\mathrm{EE}$ is configured in a complex and evolving field, and, therefore, in movement, and that dialectically covers aspects of reality related to its objective, subjective and intersubjective dimensions (see for example WALS et al, 2013). In this context, participants in the meeting emphasized the importance of such complexity's being acknowledged and known, so researchers in the process of training can construct actual contributions. In other words, this was a warning for them to gain good understanding of the

\footnotetext{
${ }^{6}$ The authors of this article were responsible for facilitating the workshop "Training Policies for Researchers", one of the sub-topics proposed for further discussion by the organizing committee of the event, whose central theme, as previously mentioned, was "What is critical about contemporary "critical" environmental education research: theoretical challenges, tensions, applications, methodological implications?”
} 
field before reaching conclusions.

A second aspect raised by seminar participants referred to the possibilities of research advisors' fostering paths for the construction of a culture of reflexivity. The culture of reflexivity would be the political attitude proposed by researchers in critical EE as a form of countering the culture of performativity. In practice, the promotion of reflexivity is associated with the allocation of more time and greater attention to the stages of analysis, interpretation and theorization of research data, which is often left in the background in relation to the stage of data generation.

In turn, a greater investment in processes of data analysis, interpretation and theorization, is seen by researchers as directly associated with time management, and it is configured as a common challenge for different realities. Typically, researchers training occurs in a "countdown" condition, as researchers are faced with deadlines imposed by their programs or funders. Thus, the more their research advances, the less time there is for its completion, so that less time and attention tend to be allocated to its final stages, which are characterized as a fundamental step for the critical reflection of the results generated. In this context, the quality of data generated does not make much of a difference, since the reduced time for analysis can cause them to be underused. Thus, it is necessary for in-training researchers to be attentive to the schedule of their research and to assign privileged time to its final stages.

Also as a way to promote the culture of reflexivity, a greater attention to conceptual unveiling was suggested in the event. With this regard, the suggestions raised in the seminar agree with the warnings made by Freire (1987) concerning the use of "hollow words", which are words or phrases commonly used, but which are not accompanied by precise corresponding definitions. According to the author, such words become slogans, which are seductive and, therefore, often replicated, but which are poor for processes of meaning construction. Therefore, critical discourses should be aware of these "empty words" and seek their location and unveiling, in a movement that starts from an unclear generalization (and, therefore, of inappropriate use) for the explication of the meanings implied in them.

A third aspect pointed out by researchers regarding the creation of a culture of reflexivity refers to the possibilities of constructing communities of research practices, which constitute spaces of dialogue involving advisors and training researchers. At the same time, they aim at the creation of group identities and the cultivation of a research culture based on collectivity, solidarity, cooperation and articulated initiatives. Study groups, interventions and collective research, field trips and collective text writings are examples of actions that can be developed with the purpose of producing a community of practice. In this way, such communities create atmospheres that are clearly different from the traditional performative research culture, of isolation, competition, and individualism.

Another strategy raised in the seminar that emphasizes resistance against performativity is associated with actions aimed at improving the ability of supervisors to carry out activities that have as aims to prepare critical EE researchers. The rationale here is that since, as a rule, there is not any type of training spaces for supervisors, they basically inherit their culture from their own supervisors. In doing so, it is much more likely that they reproduce their supervisor's practice, sometimes very much in line with the reproduction of the culture of performativity. In some seminar's participants experiences with their own supervisors, as graduate students, there were not much space for contemplation, critical reflection or innovation. In practice, it was suggested that seminars should be organized for supervisors' guidance and that they should focus on "the practice of supervision". In such a way, research supervisors would have the opportunity to better reflect and understand their role and the implications of their choices for themselves, their advisees and the researchers' community in general. 
A final suggestion made at the seminar was that the scientific community of EE researchers should actively participate in the construction of evaluation policies in their teaching and research institutions in order to review their evaluation criteria for supervisors and programs. The global culture of performativity puts enormous pressure on universities to value supervisors and programs almost exclusively based on academic production, and more specifically through publications. This procedure ultimately excludes many aspects of academic life and, in the same way, instigates the incorporation of that culture.

\section{Final Considerations}

Probably we are not wrong to recognize as an international trend - to which Brazil adheres completely - that graduation programs are responsible for researchers' training, during the development of their master and doctorate studies. Nowadays, also as an international trend, these programs are under evaluation policies that are heavily influenced by market criteria and the underlying assumption of competitive performativity. These criteria can ultimately affect the performance of the individuals involved and influence not only the subjects studied, but also how investigations are carried out. In addition, they can mark out the contents that will be appropriated by the researchers undergoing the preparation process as well as the ways of producing knowledge. Put differently, overemphasis and preoccupation with evaluative market forces jeopardizes, or risks, the autonomy of both researchers and their institutions/organizations.

As we have tried to point out in this paper, these trends have brought, perhaps unwittingly, negative consequences for all processes of knowledge production in different areas of knowledge. Particularly, this context poses challenges for the field of Environmental Education Research (EER) and for the processes of researchers' training in this field. As a relatively new field, and the same time complex and transboundary area, EER is continually challenged and vulnerable when we consider such trends.

As Wals et al (2013) have pointed out, in discussing directions for EE in times of uncertainty, we must fundamentally learn to deal with controversy and contestation. Thus, "time, careful thought, and reflexivity [...] are required to sort through the vast and often conflicting sources of information and knowledge claims" (WALS et al, 2013, p. 543). In such contexts, an overemphasis on pragmatic views and attitudes, at a cost of reflection and theorization, can be damaging to overall knowledge production. Zizek (2011, p. 23) provocatively argues that perhaps we have done much "[...] and now it is time to take a step back, to think and say the right thing." This is the time to theorize.

From this, we think it is worth turning to Payne's (2009) useful considerations, when this researcher recognizes that a challenge or threat is presented by globalized policies and the transformation of knowledge structures and their abstracted means of production. Following this author, we can see in different countries and all over the world that "despite the proliferation of curriculum/pedagogical currents and emergence of new research genres, relatively conservative tendencies in environmental education research persist" (PAYNE, 2009, p. 66). This author, based in other researchers, argues that this characteristic "is located in a 'post-intellectual' form where we find it difficult to see how we individually and collectively have been incorporated into an abstracted, corporate driven form of knowledge production" (PAYNE, 2009, p. 66). It is noteworthy, for example, that the same tendency pointed out by Payne (2009) that the approach and design of EE research that have been published in the North / East countries tend to constitute a "one model fits all" approach, can be found in the Brazilian EE research journals. According to Payne (2009), and we agree that this same tendency can be seen in Brazilian EE research, "much research is [he is referring to EE research], in fact, not conceptually and/or theoretically driven but is 'evaluation' where, 
basically, an intervention is devised and its variables are identified and measured for significance of change" (p. 66). In his paper, the author concludes that the kind of research evaluation "mirrors a conservative positivist view of knowledge production and value", "reductionist view of the sample and the phenomena under study", "semi-experimental design and case or comparative study approach" (PAYNE, 2009, p. 66). In certain ways this kind of research is much more convenient and fits well the demands we have under performative policies of knowledge production.

The challenges for EE research from now is to deal with "a more vital and, possibly, dynamic and critical view of research development and inquiry in environmental education" (p. 66). In other words, this author summarized his idea saying that it is time to "confront and critically examine our research frames, designs and methodologies. Researchers have "to be very clear about the purposes, rationale, processes, contribution, value and usefulness of our individual and collective research efforts" (p. 67)

Considering what we could bring to the surface with the group discussions and the strategy that different research have trying to resist to this performative and quantitative policies, we would like to leave an invitation. As we have emphasized in other opportunities (see for example, CARVALHO, 2016), we would like to invite young researchers, supervisors and seniors, each one who is committed with the social practice of producing scientific knowledge, that our commitment with it becomes a commitment with all forms of life and with diversity. A commitment to producing multiple, diverse and creative meanings for life and for the relationship between human beings, non-human animals and nature. Commitment as Leff (2002) has proposed: to think the yet not thought.

Similar to any other field of research, critical EE research also seeks to find, challenge, and overcome boundaries of knowledge. However, during the seminar, participants pointed out that this search should be done in a way that it also affirms researchers' positions against the culture of performativity and its consequences, and avoid them.

\section{References}

ARCHER, L. Younger academics' constructions of 'authenticity', 'success' and professional identity. Studies in Higher Education, Vol. 33, No. 4, August 2008, 385-403.

AROCENA, R.; SUTZ, J. Changing knowledge production and Latin American universities. Research Policy, 30 (2001). P. 1221-1234

BIANCHETTI, L.; MACHADO, A. M. N. "Reféns da produtividade": sobre produção do conhecimento, saúde dos pesquisadores e intensificação do trabalho na pós-graduação. In: $30^{\mathrm{a}}$ REUNIÃO ANUAL DA ANPED.,30, 2007, Caxambu. Anais...Caxambu: Associação Nacional de Pós-Graduação em Pesquisa em Educação.1 CD.

BOGLE, D.; DRON, M.; EGGERMONT, J.; VAN HENTENA, J. W. Doctoral degrees beyond 2010: training talented researchers for society. Procedia Social and Behavioral Sciences, v. 13, p, 35-49, 2011. 
CARVAlHO, L. M. Pesquisa em Educação Ambiental no Brasil: um campo em construção? 2015 (Tese de Livre-Docência). Universidade Estadual Paulista "Júlio de Mesquita Filho". Rio Claro, SP, Brasil. 2016.

CARVALHO, L.M.; TOMAZELlO, M.G.C.; OLIVEIRA, H.T. Pesquisa em educação ambiental: panorama da produção brasileira e alguns de seus dilemas. Cadernos CEDES, v. 29, p. 13-28, 2009.

COOPER, S. Post-Intellectuality? In: COOPER, S.; HINKSON, J.; SHARP, G. Scholars and Entrepeneurs - The universities in crisis. North Carlton, Australia: Arena Publications Association. 2002. p.207-232.

COOPER, S.; POLETTI, A. The new ERA of journal ranking: The consequences of Australia's fraught encounter with "quality". Australian Universities Review, v. 53, n.1, p. 57-65, 2011

FANG, F. C; CASADEVALL, A. Competitive Science: Is Competition Ruining Science? Infection and Immunity, V. 83 N. 4, April 2015, Editorial, p. 1229 - 1233.

FREIRE, Paulo. Pedagogia do oprimido. 26. ed. Rio de Janeiro: Paz e Terra, 1987.

FREITAS, S. F. T de. Mais algumas notas sobre a transição da pós-graduação brasileira. Revista Brasileira de Pós-graduação, v. 8, n.15, 2011.

GILL, R Breaking the silence: The hidden injuries of neo-liberal academia in Flood, R. \& Gill,R. (Eds.) Secrecy and Silence in the Research Process: Feminist Reflections. London: Routledge, 2009.

GOERGEN, P. Ciência, sociedade e universidade. Educação \& Sociedade, v. 19, n. 63, 1998.

GOLDANI, M. Z, SILVA, C. H. DA, NASCIMENTO, L. F. M DO; BLANK, D. A questão da produção do conhecimento: desafios na gestão dos programas de pós-graduação. Revista Brasileira de Pós-graduação, v. 7, n. 12, p. ??, 2010.

JAMES, P.; McQUEEN-THOMSON, D., Abstracting knowledge formation: A report on academia and publishing. In: COOPER, S.; HINKSON, J.; SHARP, G. Scholars and Entrepeneurs - The universities in crisis. North Carlton, Australia: Arena Publications Association. 2002

LEATHWOOD, C.; READ B. Research policy and academic performativity: compliance, contestation and complicity. Studies in Higher Education, vol. 38, n. 8, p. 1162-1174. 2013.

LEFF, H. Epistemologia Ambiental. São Paulo: Cortez, 2002.

LUCAL, B. Neoliberalism and Higher Education: How a Misguided Philosophy Undermines Teaching Sociology. Teaching Sociology 2015, Vol. 43(1) 3-14

MASSCHELIEN, J.; SIMONS, M. From active citizenship to a world citizenship: a proposal for a world university. European Educational Research Journal, v. 8, n. 2, p. 236-248, 2009.

MOREIRA, A. F. A cultura da performatividade e a avaliação da pós-graduação em educação no Brasil. Educação em Revista, Belo Horizonte, v. 25, n. 3, p. 23 - 42. 2009.

OLIVEIRA, M. R, ALMEIDA, J. Programas de pós-graduação interdisciplinares: contexto, contradições e limites do processo de avaliação Capes. Revista Brasileira de Pós-graduação, v. 8, n.15, 2011. 
OSTERLOH, M; FREY, B.S. Research Governance in Academia: Are there Alternatives to Academic Rankings? CESIFO WORKING PAPER NO. 423, Aug. 2009.

PAYNE, P. Framing Research: Conceptualization, Contextualization, Representation and Legitimization. Pesquisa em Educação Ambiental, v. 4, n. 2, 2009

ROBOTTOM, I.; HART, P. Research in Environmental Education: engaging the debate. Geelong, Australia, Deakin University Press. 1993. 81 p.

SANTOS, B. de S. A universidade do Século XXI: para uma reforma democrática e emancipatória. São Paulo: Cortez, 2004.

SEVERINO, A. J. Educação e universidade: conhecimento e construção da cidadania. Interface, v. 6, n. 10, p: $117-124,2002$

SEVERINO, A. J. A avaliação no PNPG 2005-2010 e a política de pós-graduação no Brasil. In: FERREIRA, N. S. C. (Org.). Políticas Públicas e Gestão da Educação: polêmicas, fundamentos e análises. Brasília: Líber Livro Editora, 2006.

SEVERINO, A. J. Pós-graduação e pesquisa: o processo de produção e de sistematização do conhecimento. Revista Diálogo Educacional, v. 9, n. 26, janeiro-abril, p. 13-27, 2009.

SGUISSARDI V. A avaliação defensiva no "modelo CAPES de avaliação" - É possível conciliar avaliação educativa com processos de regulação e controle do Estado? Perspectiva, Florianópolis, v. 24, n. 1, p. 49-88, jan/jun. 2006.

SIMONS, M.; MASSCHELEIN, J. Towards the idea of a world university. Interchange, v. 40/1, p. 123, 2009.

SMEYERS, P.; BURBULES, N.C. How to improve your impact factor: questioning the quantification of academic quality. Journal of Philosophy of Education, v. 45, n.1, 2011.

WALS, A. E.J.; STEVENSON, R. B.; BRODY, M.; DILON, J. 2013. Tentative directions for environmental education research in uncertain times. In: STEVENSON, R.B. et al. International Handbook of Research on Environmental Education. New York and London: Routledge, 2013. p. 542547.

WALS, A.E.J.; DILLON, J. Conventional and emerging learning theories: Implications and choices for educational researchers with a planetary consciousness. In: STEVENSON, R.B. et al. International Handbook of Research on Environmental Education. New York and London: Routledge, 2013. p. 253261.

SOBRAL, F. A. F. Educação para a competitividade ou para a cidadania social. São Paulo em Perspectiva, v. 14, n. 1, p: 1-11, 2000.

YAMAMOTO, O. H., TOURINHO, E. Z., BASTOS, A. V. B, MENANDRO, P. B. M. Produção científica e "produtivismo": há alguma luz no final do túnel. Revista Brasileira de Pós-graduação, v. 9, n 18, 2012.

ZIZEK, SLAVOJ. Primeiro como tragédia, depois como farsa. São Paulo: Boitempo. 2011. (Leitura e discussão do Cap. 2: A Hipótese Comunista). 